${ }^{1}$ V. N. Karazin Kharkiv National University, Kharkiv, Ukraine; ${ }^{2}$ Zoological Institute, Russian Academy of Sciences, St. Petersburg,

Russia; ${ }^{3}$ Tambov State University, Tambov, Russia; ${ }^{4}$ Institute of Cytology, Russian Academy of Sciences, St. Petersburg, Russia

\title{
Gamete production patterns and mating systems in water frogs of the hybridogenetic Pelophylax esculentus complex in north-eastern Ukraine
}

\author{
Olha V. Biriuk ${ }^{1}$, Dmitriy A. Shabanov ${ }^{1}$, Alexey V. Korshunov ${ }^{1}$, Leo J. Borkin ${ }^{2}$, Georgy A. Lada ${ }^{3}$, Rosa A. \\ Pasynkova $^{4}$, Jury M. Rosanov ${ }^{4}$ and Spartak N. LitvinchuK ${ }^{4}$
}

\begin{abstract}
Hybridization and polyploidy play an important role in animal speciation. European water frogs of the Pelophylax esculentus complex demonstrate unusual genetic phenomena associated with hybridization, clonality and polyploidy which presumably indicate an initial stage of reticulate speciation. The Seversky Donets River drainage in north-eastern Ukraine is inhabited by both sexes of the diploid and triploid hybrid P. esculentus and only one parental species Pelophylax ridibundus. Based on the presence of various types of hybrids, all populations studied can be divided into three geographical groups: I) $P$. ridibundus $-P$. esculentus without triploids; II) $P$. ridibundus $-P$. esculentus without diploid hybrids; and III) $P$. ridibundus $-P$. esculentus with a mixture of diploids and triploids. A study of gametogenesis revealed that diploid $P$. esculentus in populations of the first type usually produced haploid gametes of $P$. ridibundus and a mixture of haploid gametes that carried one or another parental genome (hybrid amphispermy). In populations of the second type, hybrids are derived from crosses of $P$. ridibundus males with triploid hybrid females producing haploid eggs with a genome of $P$. lessonae. Therefore, we suggest that clonal genome duplication in these eggs might be the result of suppression of second polar body formation or extra precleavage endoreduplication. In populations of the third type, some diploid females can produce diploid gametes. Fertilization of these eggs with haploid sperm can result in triploid hybrids. Other hybrids here produce haploid gametes with one or another parental genome or their mixture giving rise to new diploid hybrids.
\end{abstract}

Key words: Polyploidy - gametogenesis - hybrid amphispermy - DNA flow cytometry - genome size

\section{Introduction}

Hybridization plays an important role in animal speciation (Arnold 2006; Mallet 2007, 2008; Borkin and Litvinchuk 2013). This process may lead to polyploidy, because discordance of two different parental genomes would interfere with meiosis and could result in formation of gametes with unreduced DNA content. As a general rule, the larger genetic divergence of parental species, the higher the frequency of polyploids among hybrid progeny (Bogart and Bi 2013). Tetraploidy may be favoured in hybrids when normal meiosis could be completed, and reproductive barriers are established between parental and newly originated species (Otto and Whitton 2000). Although tetraploid species can arise from diploid ancestral ones immediately, more often they pass via an intermediate triploid stage (Borkin and Darevsky 1980; Cunha et al. 2008). Triploidy is widely seen in the Pelophylax esculentus complex of European water frogs. Some authors recognized hybridization and polyploidization in water frog populations as an initial stage of reticulate speciation (Borkin and Darevsky 1980; Graf and PollsPelaz 1989a; Christiansen and Reyer 2009).

The edible frog named Pelophylax esculentus (Linnaeus, 1758) according Frost et al. (2006) formerly assigned to the genus Rana Linnaeus, 1758 sensu lato. P. esculentus is widely distributed in temperate Europe and consists of numerous genetic lineages of hemiclonal or meroclonal di- and polyploid hybrids (e.g. Plötner 2005; Hoffmann et al. 2015). The species originate from crosses of Pelophylax lessonae (Camerano, 1882) (genotype LL) and Pelophylax ridibundus (Pallas, 1771) (genotype $\mathrm{RR}$ ). The hybrids are characterized by special mechanism of

Corresponding author: Olha V. Biriuk (mykhailova.o.v@gmail.com) Contributing authors: Dmitriy A. Shabanov (d.a.shabanov@gmail.com); Alexey V. Korshunov (alexeyykorshunov@gmail.com); Leo J. Borkin (leo.borkin@zin.ru); Georgy A. Lada (esculenta@mail.ru); Rosa A. Pasynkova (rozaabr@yandex.ru); Jury M. Rosanov (rozanov@mail. cytspb.rssi.ru); Spartak N. Litvinchuk (litvinchukspartak@yandex.ru) clonal inheritance firstly discovered in small gynogenetic Mexican fish of the genus Poeciliopsis Regan, 1913 and named hybridogenesis (Schultz 1969; Tunner 1974). However, cytogenetic mechanisms seem to be different in all-female fish and bisexualunisexual frogs. Cytologically hybridogenesis in water frogs is more complicated than in Poeciliopsis fish (Dawley 1989; Vinogradov et al. 1990). In the gametogenesis of hybridogenetic frogs, the entire genome of one parental species is selectively eliminated; therefore, hybrids pass the genome of another parental species to progeny without crossing-over or segregation (nonrecombined chromosome set). Such a phenomenon results from a premeiotic exclusion of one parental genome with subsequent duplication of the remaining one. The genome duplication restores diploid chromosome number. Then, these two identical chromosome sets pass through meiosis and give rise to clonal gametes. This model was confirmed by detailed studies of spermatogenesis and oogenesis of $P$. esculentus (Tunner and Heppich 1981; Heppich et al. 1982; Borkin et al. 1987; Graf and PollsPelaz 1989a; Ragghianti et al. 2007; Dedukh et al. 2015).

Many populations of the $P$. esculentus complex include triploids and even tetraploids (in evidently rarer cases) besides diploid individuals (genotype LR) (e.g. Jakob 2007; Hoffmann et al. 2015). Two main types of triploid frogs differing by genome composition were found in the wild. Some of them have one genome of $P$. lessonae and two genomes of $P$. ridibundus (genotype LRR), while others have two genomes of $P$. lessonae and one genome of $P$. ridibundus (genotype LLR). Mass occurrence of triploid $P$. esculentus was mostly registered in northern Germany, Denmark, southern Sweden, western Poland and western Hungary (Günther et al. 1979; Tunner and Heppich-Tunner 1992; Rybacki and Berger 2001; Arioli et al. 2010).

Many authors have focused on the study of mating systems and gamete variety derived from hybrids in diverse population systems. It should be mentioned that various hybrids can also differ in gamete types which they produce. For instance, in systems in which hybrids coexist with Pelophylax lessonae, P. esculentus usually transmit the ridibundus ( $\mathrm{R})$ genome to progeny as 
evidenced by artificial crosses, chromosome, DNA flow cytometry and allozyme analyses (Uzzell et al. 1977, 1980; Graf and Müller 1979; Tunner and Heppich 1981; Borkin et al. 1987). Nevertheless, occasionally hybrids supplied haploid gametes with lessonae (L) genome, diploid gametes with LL and RR genotypes, and a small fraction of gametes carrying recombined haploid genome (Tunner 1980; Günther 1983; Gunther and Plötner 1988; Graf and PollsPelaz 1989a). Furthermore, in some systems individuals with two germ cell lineages carrying genomes of different parental species were revealed (Vinogradov et al. 1990, 1991). This remarkable phenomenon was named hybrid amphispermy.

Gametogenesis in triploid hybrids usually includes a stage of selective exclusion of the genome (chromosome set) which is represented by a single copy. For instance, the eliminated genome is the L genome in LRR frogs, but the R genome in LLR ones. Germ cells with remaining double genome of either parental species (LL or RR) enter meiosis and usually give haploid gametes (Günther et al. 1979; Vinogradov et al. 1990). However, sometimes triploid males of P. esculentus (LLR) can produce diploid LL sperm (Graf and PollsPelaz 1989b; Mikulicek and Kotik 2001; Pruvost et al. 2013). Also in one known case an LLR female produced both diploid and haploid gametes at the same time (Christiansen 2009).

About 10 years ago mass polyploidy in P. esculentus was discovered in the middle stretch of the Seversky (=Siverskyi) Donets River (Borkin et al. 2004, 2005, 2006). This territory proved to be unique in terms of quite diverse population systems and was named the Seversky Donets centre of genetic diversity of green frogs (Shabanov and Litvinchuk 2010; Dedukh et al. 2015). Moreover, recently it was found that $R$ and $L$ genomes in hybrids from the centre may represent independent evolutionary lineages (Hoffmann et al. 2015). Here, we found RR populations, and various types of population systems containing hybrids (Borkin et al. 2004, 2005, 2006; Korshunov 2010). Triploid $P$. esculentus frogs are distributed along the Seversky Donets River over an area over $480 \mathrm{~km}$ in length in Kharkiv, Donetsk and Luhansk oblasts of Ukraine and in Rostov Oblast of Russia. It is important to emphasize that the Seversky Donets centre of polyploid hybrids is geographically pronouncedly isolated from other centres with polyploidy in central Europe, being separated by a distance of approximately $1000 \mathrm{~km}$ from the nearest locality in north-eastern Poland (Schröer 1996) and $1500 \mathrm{~km}$ in western Hungary (Tunner and Heppich-Tunner 1992). Our data were confirmed by other researchers (Manilo et al. 2007; Mezhzherin et al. 2007, 2010; Morozov-Leonov et al. 2007; Manilo and Radchenko 2010; Suryadna 2010; Rostovska 2011; MorozovLeonov 2014; Hoffmann et al. 2015). Nevertheless, the gamete production pattern in diploid and triploid hybrid frogs inhabiting the Seversky Donets River drainage is still poorly understood.

This study focused on the diversity of mating systems and gamete types in hybrid $P$. esculentus from populations of various types located in the Seversky Donets centre. This study is important to clarify the origin and reproduction of diploid and polyploid hybrids in various population systems.

\section{Materials and Methods}

Between 2005 and 2013, a total of 455 adult green frogs were collected in 18 localities of the Kharkiv, Donetsk and Luhansk oblasts in eastern Ukraine (Table 1; Fig. 1). There were 269 individuals of P. esculentus and 186 individuals of $P$. ridibundus. Additionally, 49 individuals of P. lessonae from Mari El Republic of Russia were used because no adults of this species were found in the Seversky Donets centre. Species identity for each individual was determined by genome size (see below). Each individual was anaesthetized by methoxyethane or submersion in a
$1 \%$ solution of 3 -aminobenzoic acid ethyl ester (MS 222). After anaesthesia, samples of blood and gonads were taken. All specimens and samples were newly collected and analysed. All specimens studied are deposited at the Museum of Nature, V. N. Karazin Kharkiv National University (Kharkiv, Ukraine) and the Zoological Institute of Russian Academy of Sciences (St. Petersburg, Russia). The sampling localities and sample details are provided in Table 1 and Fig. 1. Materials used to determine polyploid frequency among hybrids were described in our previous publications (Borkin et al. 2004; Shabanov 2015). The existence of P. ridibundus in some populations was determined by mating calls only (Severodonetsk) or by mating calls and morphological data as well (Lypkuvativka and Merefa).

The content of DNA per nucleus (or genome size) in erythrocytes was measured by DNA flow cytometry in 504 frogs (Table 1). This method allows each frog to be identified reliably in terms of species identity, hybridity and ploidy level as well as genome composition in polyploids (Borkin et al. 1987, 2004). Red blood cells were taken from the heart using a micropipette. Tested cells were mixed with reference cells and assayed simultaneously. Therefore, in such a mixture, both kinds of cell samples were stained and measured in the same conditions. Peripheral blood cells of the grass frog, Rana temporaria Linnaeus, 1758, collected in north-western Russia were used as a reference standard.

The cell samples were suspended in phosphate buffer saline, supplemented with $0.7 \mathrm{mM}$ EDTA (ethylenediaminetetraacetic acid) $(\mathrm{pH} 7.5$ ), with a total cell concentration of approximately $10^{6}$ cells $\mathrm{ml}^{-1}$. The cells were lysed by the addition of Triton X-100 (Ferak, Berlin) at a final concentration of $0.1 \%$ and stained with a mixture of olivomycin (OM; Moscow Medicine Plant, Moscow, Russia) and ethidium bromide (EB; Calbiochem San Diego, CA 92121 United States) at the following final concentration: $20 \mu \mathrm{g} \mathrm{ml}^{-1} \mathrm{~EB}, 40 \mu \mathrm{g} \mathrm{ml}^{-1} \mathrm{OM}$ and $15 \mathrm{mM} \mathrm{MgCl}_{2}$. Stained cell samples were measured after $24 \mathrm{~h}$ (at $4^{\circ} \mathrm{C}$ ).

Flow cytometry was performed by the use of microscope-based flow fluorimeter with mercury-arc lamp as a light source, constructed at the Institute of Cytology, Russian Academy of Sciences, St. Petersburg. The conditions of fluorescence excitation and registration were optimized for the method of staining. DNA histograms were acquired with a multichannel analyser connected with a microcomputer. The analysis rate was 100-200 cells per second; four runs were performed on each sample, with the total number of cells measured per sample being above 10000 . The peaks of DNA histograms were fitted to the Gaussian curves by means of the least-square technique. Coefficients of variation of these peaks were in the range $1.5-2.0 \%$. In arbitrary units, genome size of an individual under the study was determined as the ratio of its cell peak mean to that of $R$. temporaria. The average genome size of the species is equal to $10.32 \mathrm{pg}$ (Borkin et al. 2001). Some other details of the technique have been published previously (Vinogradov et al. 1990; Borkin at al. 2001)

DNA flow cytometry was also applied to identify genome types in sperm cell suspension from testes (Vinogradov et al. 1988, 1990). A total of 166 males of $P$. esculentus, six males of $P$. ridibundus and 12 males of $P$. lessonae were examined. Spermatozoa of $R$. temporaria were used as reference cells. When cells carried a haploid genome equal to that of $P$. ridibundus or $P$. lessonae, it was marked as $\mathrm{R}$ or $\mathrm{L}$ genome, respectively. When cell suspension from the testes of a hybrid male contained two haploid genomes of both parental species (hybrid amphispermy), it was marked as $\mathrm{R}+\mathrm{L}$ mixture of gametes. When a haploid genome had intermediate nuclear DNA content between P. ridibundus or P. lessonae, we recognized these cells as gametes with intermediate genome (int). In cases of low content or absence of haploid cells in testes cell suspensions $(<10 \%$ from total number of analysed cells), we have defined it as 0 (zero). Some adult males of $P$. esculentus had translucent and very small testes $(<4 \mathrm{~mm}$ length); hence, we defined them as reduced gonads. The screening of testes cell suspension smears was performed in phase contrast to analyse the cell composition (spermatozoa, spermatids, spermatocytes, etc.).

Sometimes, testes were treated by two techniques: one testicle was used for taking cell suspension for DNA flow cytometry, while the second was used for karyological analysis. The last was fixed in one part of glacial acetic acid and three parts of methanol. Karyological slides of spermatocytes from testes were studied in 18 males of $P$. esculentus, nine males of $P$. ridibundus and three males of $P$. lessonae (Table 1). The males were injected with $0.3-0.5 \mathrm{ml}$ of $0.4 \%$ colchicine water solution 


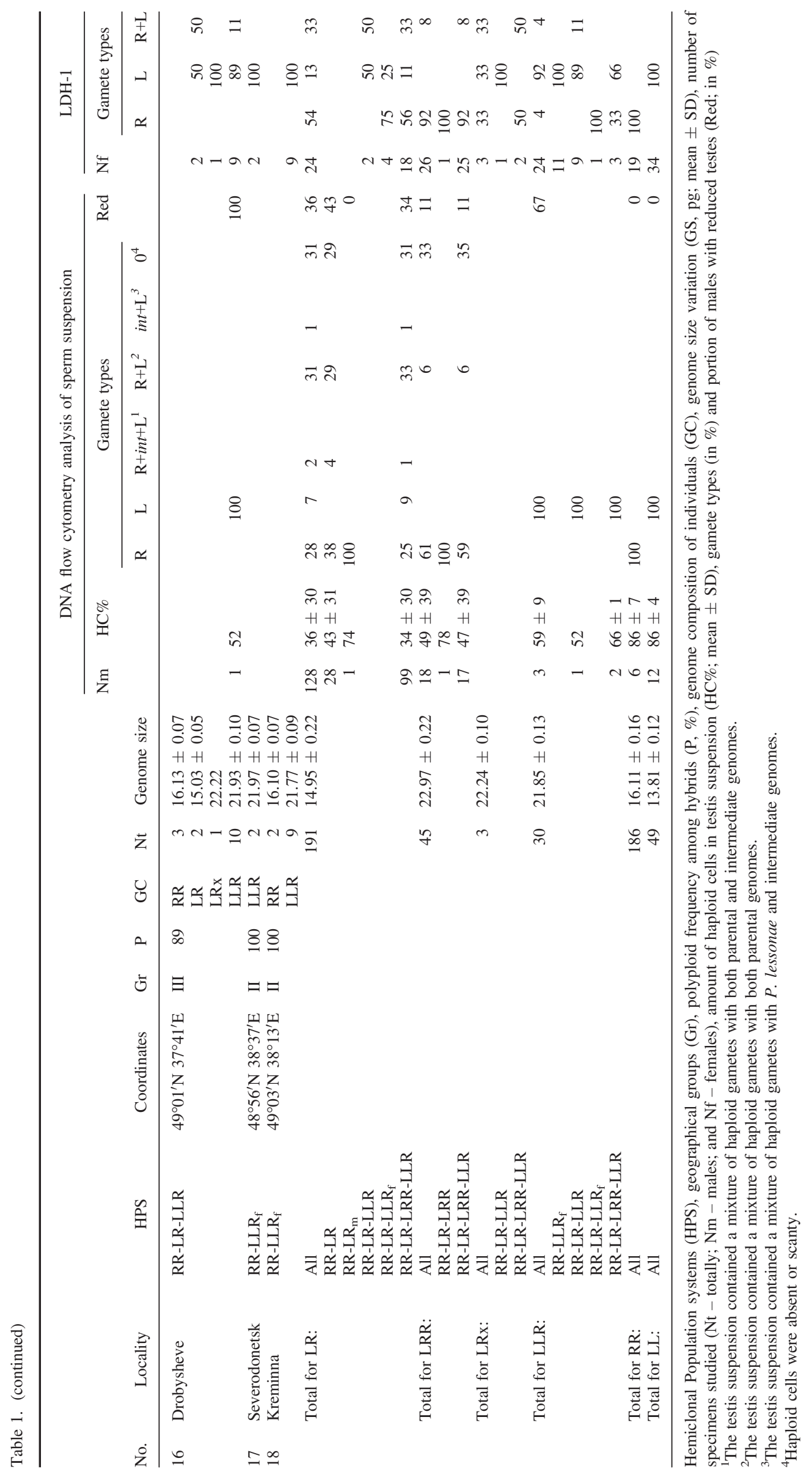




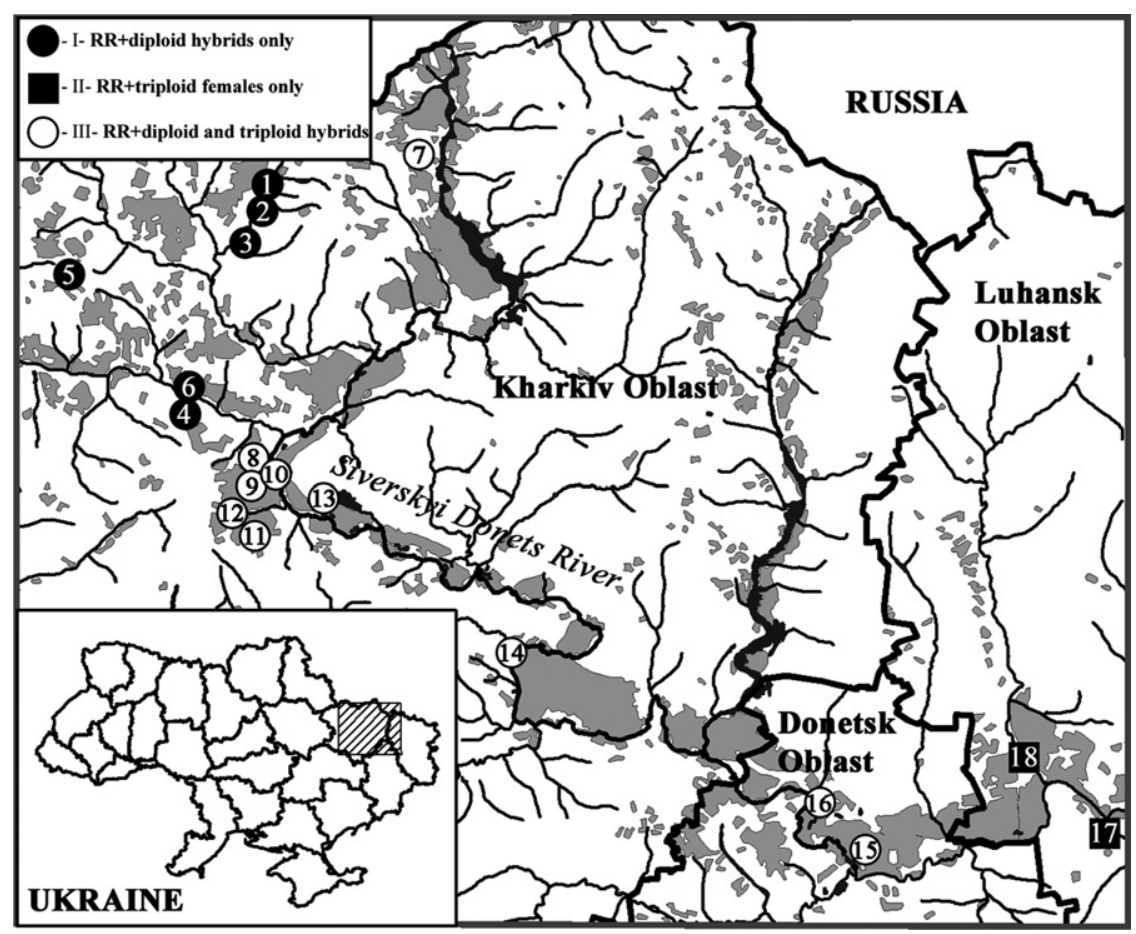

Fig. 1. Sampling localities in the Seversky Donets River drainage in north-eastern Ukraine. Forests are marked by grey colour. Sample numbers are the same like in Table 1. Group I is designated by black circles. These sites are inhabited by Pelophylax ridibundus and diploid Pelophylax esculentus only. Group II is designated by black square boxes. These population systems include P. ridibundus and LLR females. Group III is designated by open circles and characterized by compulsory presence of triploids, besides diploid $P$. esculentus and $P$. ridibundus

1 day before tissue collection. Before fixation, tissue samples were kept in hypotonic $0.07 \mathrm{M} \mathrm{KCl}$ solution for $12 \mathrm{~min}$. Then, tubes with tissue samples were centrifuged at $755 \mathrm{~g}$ in hypotonical solution for $2 \mathrm{~min}$, supernatant liquid was poured out, and samples were fixed. Fixative was changed three times each $30 \mathrm{~min}$ of incubation. Later, treated tissue fragments were kept in $60 \%$ acetic acid water solution, and cell suspension was dropped on glass slides heated up to $60^{\circ} \mathrm{C}$. The slides were stained in a $2 \%$ Giemsa solution for $1 \mathrm{~min}$, rinsed and air-dried.

Genomes in mature oocytes were identified by protein electrophoresis. We used Lactate dehydrogenase (LDH-1) previously found useful in discriminating $P$. ridibundus and P. lessonae (Uzzell et al. 1980; Mikulíček et al. 2015). Oocytes of 76 frogs of $P$. esculentus, 19 females of $P$. ridibundus and 34 females of $P$. lessonae were studied (Table 1). Before allozyme analysis, collected tissues were stored at $-80^{\circ} \mathrm{C}$. Standard vertical polyacrylamide gel $(6 \%)$ electrophoresis was performed to analyse the genetic variation. For electrophoresis, we used Tris-citrate $\mathrm{pH} 8.0$ buffer.

It is known that in the majority of localities, $P$. esculentus coexist and reproduce with either or both parental species, forming various mixed populations (e.g. Rybacki and Berger 2001). Such a mixed populations were named hemiclonal population systems (HPS) (Shabanov and Litvinchuk 2010). In such systems, the reproductive process is based on mechanisms of both recombinant (Mendelian) and clonal inheritance. Therefore, this term cannot be applied to populations without successfully reproducing $P$. esculentus. Several classifications of green frog population systems were proposed to characterize populations comprised of different species (Günther 1975a,b, 1983; Uzzell and Berger 1975; Tunner and Heppich-Tunner 1992; Lada et al. 1995; Rybacki and Berger 2001). To highlight distinctive features of the systems, we used a classification based on genome composition and sex of individuals. Thus, the RR-types mean populations which include individuals of single parental species, $P$. ridibundus. For instance, RR-LR-LLR $\mathrm{f}_{\mathrm{f}}$ type means a HPS which contains $P$. ridibundus, diploid $P$. esculentus of both sexes and triploid $P$. esculentus which are represented by LLR females (f) only.

\section{Results}

In eastern Ukraine, pure RR populations and eight types of HPS, (see Materials and Methods section for details) (RR-LR, RR-LR ${ }_{\mathrm{m}}$,

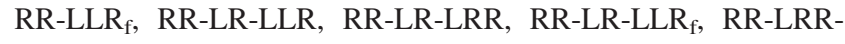
LLR and RR-LR-LRR-LLR) were revealed. Valleys of right tributaries of the Seversky Donets River (rivers Kharkiv, Udy, Lopan' and Mzha) in the northern part of Kharkiv Oblast were inhabited by pure RR populations, RR-LR, and RR-LR $\mathrm{m}_{\mathrm{m}}$ systems only (localities 1-6 in Table 1; Fig. 1). All studied individuals of P. esculentus were diploid. In the remaining part of Kharkiv Oblast and in the north-west of Donetsk Oblast within the Seversky Donets River drainage, almost all HPS included $P$. esculentus with a mixture of diploids and triploids (localities 7-16 in Table 1; Fig. 1). The north-eastern part of Donetsk Oblast and Luhansk Oblast (localities 17 and 18 in Table 1; Fig. 1) were inhabited by pure RR populations and HPS, where all hybrids were represented by triploid LLR females only (RR-LLR ${ }_{\mathrm{f}}$ ).

The majority (74.5\%) of examined hybrids were diploids with genome size range of $14.72-15.40 \mathrm{pg}$. It should be mentioned that $P$. ridibundus genome size is in a range of $15.81-16.40 \mathrm{pg}$ in the investigated region, while $P$. lessonae have genome size of 13.65-14.02 pg. Triploids with LLR genotypes (21.57$22.08 \mathrm{pg}$ ) comprised 9.7\%, while LRR triploid (22.44-23.37 pg) accounted for $14.6 \%$ (Table 1). In addition, we failed to assign to either triploid group three individuals $(1.2 \%)$ with intermediate genome size values $(22.15-22.35 \mathrm{pg})$. We provisionally marked them as LRx.

All adult males of both parental species, P. ridibundus and $P$. lessonae, had large or medium sized testes (more than $4 \mathrm{~mm}$ length). However, a significant number of hybrids (25.5\%) had reduced testes (Table 1). DNA flow cytometry has shown that the vast majority of cells in suspensions taken from testes of parental species was comprised of haploid sperms (average $86 \%$ in both $P$. ridibundus and $P$. lessonae; Table 1), while hybrids provided an average of $37 \%$ of haploid cells only. The remaining cells (mainly spermatocytes) had diploid or polyploid genomes.

The majority of LRR males (61\%) produced haploid sperm with the R genome (Table 1). Only one male produced a mixture 
of haploid gametes with genomes of both parental species (hybrid amphispermy), but gametes with the L genome were prevalent (86\% among haploid cells). Many LRR males (33\%) produced no gametes.

The LLR males were very rare $(2 \%)$, and two of the three hybrids examined had very small testes (Table 1). All three males produced sperm with haploid L genome only.

Among diploid males of $P$. esculentus, $28 \%$ yielded sperm with the $\mathrm{R}$ genome and only $7 \%$ with the $\mathrm{L}$ genome. Approximately one-third of males $(31 \%)$ produced two types of haploid gametes with genomes of parental species (hybrid amphispermy). Above one-third of diploid males (36\%) had reduced testes. Most of them produced no gametes (31\% from all LR males; Table 1$)$. Three diploid males $(3 \%)$ produced gametes with intermediate genomes (Table 1). Two frogs were collected in Is'kiv pond (locality 8), and one was captured in the vicinity of village Tsyrkuny (locality 2 ). In one male from Is'kiv pond (55\% haploid cells from total cell number), $30 \%$ of the haploid cells had an intermediate genome and $70 \%$ had the L genome. Among the gametes derived from the second frog from Is'kiv pond (with $63 \%$ of haploid cells in cell suspension), $17 \%$ had an intermediate genome, while $60 \%$ and $23 \%-\mathrm{R}$ and $\mathrm{L}$ genomes, respectively (Fig. 2). The Tsyrkuny male (42\% haploid cells) produced $57 \%$ gametes with an intermediate genome, $14 \%$ with the R genome and $29 \%$ with the $\mathrm{L}$ genome.

The analysis of meiotic metaphase plates showed that the vast majority of primary spermatocytes in both parental species $(98 \%$ in $P$. ridibundus and $97 \%$ in P. lessonae) were characterized by normal karyotypes with 13 bivalents that corresponded to the diploid chromosome set (Table 2).

A high fraction (77\%) of metaphases with 13 bivalents was observed in triploid LRR males, which produced the $\mathrm{R}$ genomes (43\% from total number of LRR males examined; Table 2). In contrast, in a LRR male which provided a gamete mixture $(\mathrm{L}+\mathrm{R})$, the portion of metaphases with 13 bivalents was significantly lower (7\%). In three LRR hybrids, with no normal gametes, we observed no spermatocytes with haploid number of bivalents (Table 2). Triploid LLR hybrids posed reduced testes and a low portion (34\%) of metaphases with 13 bivalents (Table 2).

In diploid hybrids which produced gametes with the $\mathrm{R}$ genome (22\%), metaphases with haploid number of bivalents were numerous (59\%). A diploid hybrid, which transmitted gametes with the $\mathrm{L}$ genome (11\%), was notable for a high fraction of metaphases with 13 bivalents (78\%). However, one diploid hybrid (11\%) lacking haploid gametes and five $(56 \%)$ diploid hybrids with an $\mathrm{L}+\mathrm{R}$ mixture of gametes were characterized by low counts of metaphase with 13 bivalents $(11 \%$ and $32 \%$ respectively; Table 2, Fig. 3 ).

Electrophoretic analysis of LDH-1 in mature oocytes demonstrated that parental species were characterized by specific alleles (Table 1). Triploid LRR females, as a rule (92\%), produced gametes with the $\mathrm{R}$ genomes (Table 1). Oocytes with alleles of both parental species were registered in only two frogs from Sukhaya Gomolsha village in Kharkiv Oblast (8\%). The absolute majority of LLR females (92\%) posed oocytes with the L genomes only. Nevertheless, a female from Gaidary village (Kharkiv Oblast) differed by expression of protein characteristic to $P$. ridibundus in its oocytes. In addition, a female from Drobyshevo village (Donetsk Oblast) produced oocytes with alleles of both parental species (Table 1). One LRx female from Gaidary appears to produce oocytes with $P$. ridibundus alleles only, while another LRx female from the same locality had alleles of both parental species in oocytes. In addition, an LRx female collected in Drobyshevo village produced oocytes with alleles of $P$. lessonae (Table 1). Among diploid hybrids, females producing oocytes with the $\mathrm{R}$ genome were predominant (54\%; Table 1). Oocytes with expression of a protein peculiar to $P$. lessonae were registered in $13 \%$ females, whereas alleles of both parental species were found in $33 \%$ of the females.

\section{Discussion}

Generally, $P$. esculentus should produce gametes with genome of a parental species that is lacking in a given population system to maintain its own successful reproduction and the stability of the system (e.g. Plötner 2005). In our studies since 1989 (Borkin et al. 2004), we failed to find any adult $P$. lessonae in water bodies of the Seversky Donets River drainage. That was confirmed by our current field examination. Therefore, we could expect that in the described systems hybrids should pass gametes with the $\mathrm{L}$ genome. However, such gametes were recorded in a

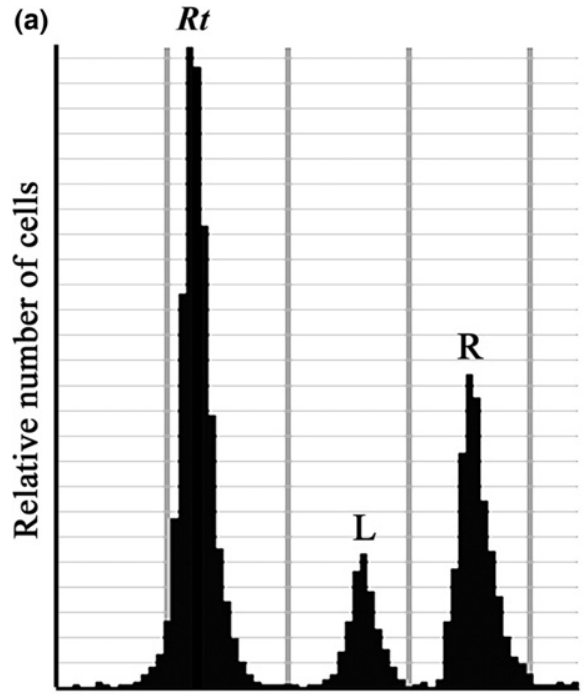

Relative DNA content (b)

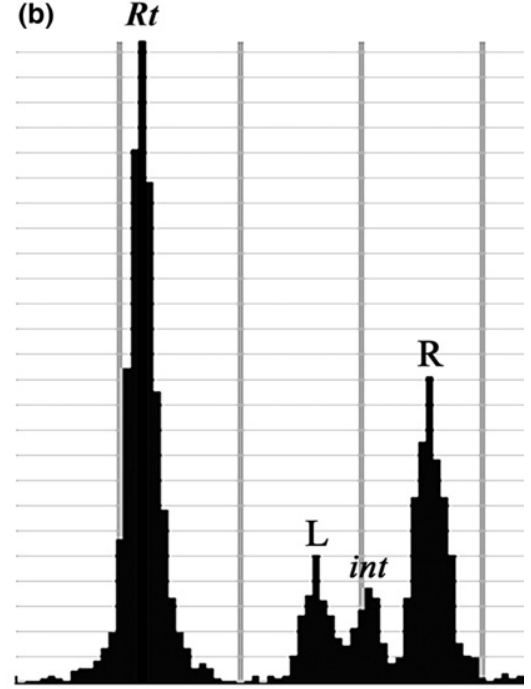

Relative DNA content

Fig. 2. DNA histograms of testes cells (haploid part of spectrum) obtained with the use of a flow fluorimeter. (a) The male of Pelophylax esculentus from Haidary which produced sperm with genomes of both parental species. (b) The male of P. esculentus from Is'kiv pond which produced sperm with genomes of both parental species and with intermediate genome. R denotes sperm with genome of $P$. ridibundus, L denotes sperm with the genome of P. lessonae, and sperm with intermediate genome is designated by int. Rt denotes sperm of Rana temporaria used as standard cells. 
Table 2. Results of a karyological analysis of testes

Karyotype occurrence

\begin{tabular}{|c|c|c|c|c|c|c|c|c|}
\hline \multirow[b]{2}{*}{ No. } & \multirow[b]{2}{*}{ Locality } & \multirow[b]{2}{*}{$\mathrm{GC}$} & \multirow[b]{2}{*}{ Gametes } & \multirow[b]{2}{*}{$\mathrm{Ni}$} & \multirow[b]{2}{*}{$\mathrm{Nc}$} & \\
\hline & & & & & & 1n & $2 n$ & $? \mathrm{n}$ \\
\hline 3 & Kharkiv City & RR & $\mathrm{R}$ & 9 & 36 & $98 \pm 4$ & 0 & $2 \pm 4$ \\
\hline \multirow[t]{6}{*}{10} & Haidary & LR & $\mathrm{R}$ & 2 & 29 & $59 \pm 1$ & $4 \pm 6$ & $37 \pm 4$ \\
\hline & & LR & $\mathrm{L}$ & 1 & 23 & 78 & 0 & 22 \\
\hline & & LR & $\mathrm{L}+\mathrm{R}^{1}$ & 5 & 63 & $32 \pm 28$ & $12 \pm 7$ & $56 \pm 22$ \\
\hline & & LRR & $\mathrm{R}$ & 2 & 38 & $75 \pm 35$ & $12 \pm 16$ & $14 \pm 19$ \\
\hline & & LRR & $\mathrm{L}+\mathrm{R}$ & 1 & 15 & 7 & 7 & 86 \\
\hline & & LRR & $0^{2}$ & 3 & 28 & 0 & $24 \pm 12$ & $76 \pm 12$ \\
\hline \multirow[t]{2}{*}{12} & Velyka Homil'sha & LR & 0 & 1 & 9 & 11 & 0 & 89 \\
\hline & & LLR & $\mathrm{L}$ & 1 & 12 & 25 & 8 & 67 \\
\hline 14 & Chepel' River & LRR & $\mathrm{R}$ & 1 & 16 & 80 & 13 & 6 \\
\hline \multirow{11}{*}{16} & Drobysheve & LLR & $\mathrm{L}$ & 1 & 46 & 43 & 22 & 35 \\
\hline & Total for RL: & & $\mathrm{R}$ & 2 & 29 & $59 \pm 1$ & $4 \pm 6$ & $37 \pm 4$ \\
\hline & & & $\mathrm{L}$ & 1 & 23 & 78 & 0 & 22 \\
\hline & & & $\mathrm{L}+\mathrm{R}$ & 5 & 63 & $32 \pm 28$ & $12 \pm 7$ & $56 \pm 22$ \\
\hline & & & 0 & 1 & 9 & 11 & 0 & 89 \\
\hline & Total for LRR: & & $\mathrm{R}$ & 3 & 54 & $77 \pm 25$ & $12 \pm 12$ & $11 \pm 14$ \\
\hline & & & $\mathrm{L}+\mathrm{R}$ & 1 & 15 & 7 & 7 & 86 \\
\hline & & & 0 & 3 & 28 & 0 & $24 \pm 12$ & $76 \pm 12$ \\
\hline & Total for RLL: & & $\mathrm{L}$ & 2 & 58 & $34 \pm 13$ & $15 \pm 10$ & $51 \pm 23$ \\
\hline & Total for RR: & & $\mathrm{R}$ & 9 & 36 & $98 \pm 4$ & 0 & $2 \pm 4$ \\
\hline & Total for LL: & & $\mathrm{L}$ & 3 & 18 & $97 \pm 5$ & 0 & $3 \pm 5$ \\
\hline
\end{tabular}

Genome composition of individuals (GC), gamete types, number of studied individuals (Ni), number of examined chromosome plates (Nc), occurrence (mean $\pm \mathrm{SD}$; in \%) of chromosome plates with bivalent sets equal to diploid (1n), tetraploid (2n) and aneuploid (?n) number

${ }^{1}$ The testis suspension contained a mixture of haploid gametes with both parental genomes.

${ }^{2}$ Haploid cells were absent or scanty $(<10 \%$ from total number of studied cells).

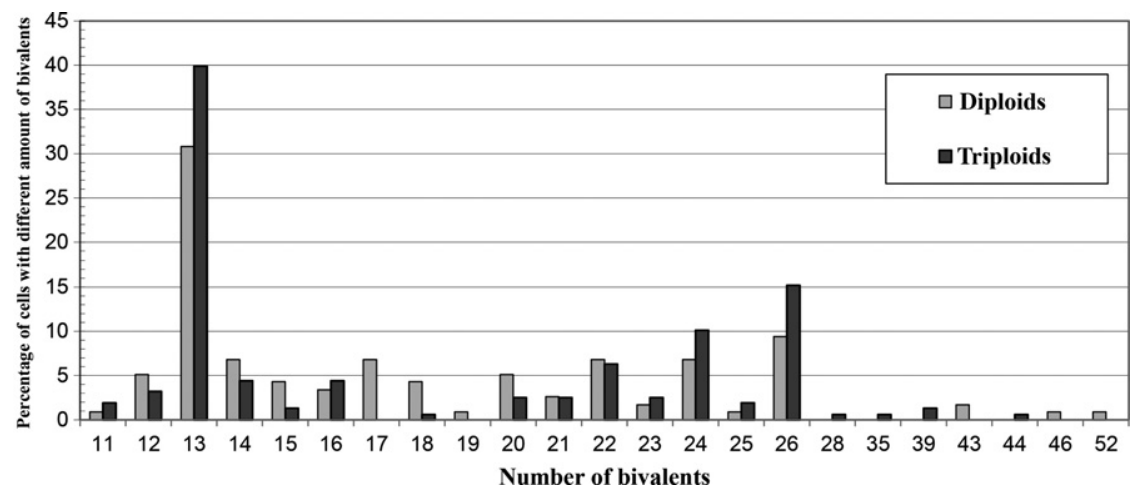

Fig. 3. Percentage of spermatocytes with different amount of bivalents obtained from testes of Pelophylax esculentus males

small number of hybrids. For instance, among diploid hybrids from the Seversky Donets drainage, only $7 \%$ of males and $13 \%$ of females were found to carry gametes with the $\mathrm{L}$ genome (Table 1).

Some individuals of $P$. esculentus produced a mixture of haploid gametes with different genomes $(\mathrm{L}+\mathrm{R}, \mathrm{L}+$ int or $\mathrm{L}+i n t+\mathrm{R})$. Notably, they can also participate in hybrid formation. Among diploid hybrids, $33 \%$ females and $31 \%$ males carried such a mixture of gametes (Table 1). However, karyological analysis of testes showed that males producing gamete mixtures, as a rule, had seriously disturbed spermatogenesis (Table 2). The analysis of lampbrush chromosomes in oocytes obtained from females producing gamete mixture revealed seriously disordered oogenesis as well (Dedukh et al. 2015).

One could suggest that reappearance of diploid P. esculentus in populations of north-eastern Ukraine is based predominantly on triploid hybrids producing gametes with the L genome. For instance, in Germany, Poland and Denmark, triploid hybrids of both kinds (LLR or LRR) render haploid gametes (Berger and Günther 1988, 1992; Vinogradov et al. 1990; Berger 1994; Christiansen et al. 2005; Pruvost et al. 2013). Indeed, triploid LLR males in our region yielded haploid gametes with the $\mathrm{L}$ genome (Table 1). In addition, some triploid LRR males (5\%) produced gamete mixtures with haploid genomes of both parental species. However, the LLR males were very rare $(2 \%)$ and were not found in most localities studied. Therefore, the suggestion mentioned above concerning the role of triploid males would be incorrect, and production of $\mathrm{L}$ gametes can be maintained predominantly by diploid hybrids.

In north-eastern Ukraine, triploid hybrids usually coexist with diploid $P$. esculentus and $P$. ridibundus and, rarely, with diploid P. esculentus only in pure hybrid HPS (Borkin et al. 2004, 2005; Korshunov 2010). Our data, concerning genome composition of sperm in triploid males, demonstrated that such males produced haploid gametes only and lacked diploid sperm (Table 1). That is true for triploid hybrids in Germany, Poland 
and Denmark as well (Berger and Günther 1988, 1992; Vinogradov et al. 1990; Berger 1994; Pruvost et al. 2013). Therefore, one possibility could be reappearance of triploid $P$. esculentus would be associated with triploid females producing diploid gametes. Indeed, diploid eggs were registered in triploid females from Germany, Denmark and Sweden (Berger and Günther 1988; Berger and Berger 1994; Christiansen et al. 2005; Christiansen 2009). However, analysis of lampbrush chromosomes in oocytes of triploid hybrids from populations in Seversky Donets River drainage demonstrated that the majority of local hybrid females produced haploid gametes only (Dedukh et al. 2015).

Thus, in this region, diploid gametes seem to be provided by diploid hybrid females. Such pattern is common in western and central Europe (e.g. Berger et al. 1978; Bucci et al. 1990; Berger and Berger 1992; Rybacki 1994b; Berger and Roguski 2002; Christiansen 2009; Christiansen et al. 2010; Pruvost et al. 2013). Moreover, lampbrush chromosome analysis revealed that some diploid hybrid females from Kharkiv Oblast (Gaidary and Velikaya Gomolsha) had oocytes with 26 bivalents as well (Dedukh et al. 2015). Fertilization of such diploid eggs by haploid sperm would result in triploid hybrids.

In some cases, diploid gametes could be produced by diploid and triploid hybrid males. Diploid sperm was identified in diploid P. esculentus in Poland, Germany, Sweden and Denmark (Vinogradov et al. 1990; Rybacki 1994a; Christiansen et al. 2005; Christiansen 2009), while triploid hybrid males with diploid sperm were recorded in France, Hungary and Slovakia (Graf and PollsPelaz 1989b; Tunner and Heppich-Tunner 1992; Brychta and Tunner 1994; Pruvost et al. 2013). However, we failed to find any hybrid male which supplied marked appreciable amount of LL or RR gametes. It is important to mention that identification of diploid RL sperm by DNA flow cytometry only would be difficult because such cells poorly differ from somatic cells of diploid hybrids in terms of genome size (Vinogradov et al. 1990). However, we used an analysis of sperm smears and found no mature spermatozoa which were larger than haploid sperm.

In several localities (nos. 17 and 18 in Table 1 and Fig. 1), triploid LLR hybrids coexisted with $P$. ridibundus and were represented by females only. Lampbrush chromosome analysis allowed to find immature oocytes with 13 bivalents with the L genome in such triploid females (Dedukh et al. 2015). Therefore, they should produce haploid eggs. Taking into consideration that LLR females in RR-LLR ${ }_{\mathrm{f}}$ HPS can mate with males of $P$. ridibundus only which supply haploid $\mathrm{R}$ sperm, it remains unclear how duplication of clonal $\mathrm{L}$ genome in triploid progeny occurs. A duplication of $\mathrm{L}$ genomes might be the result of a suppression of the formation of the second polar body (Olsen 1974; Kawahara 1978; Graf and Müller 1979; Kondo 2002) or the result of an extra precleavage endoreduplication (Zhang et al. 2015) which takes place after fertilization.

Full premeiotic exclusive elimination of a parental genome during gametogenesis was shown for frogs from populations in many countries of Europe (Uzzell et al. 1980; Heppich et al. 1982; Ogielska 1994; Morozov-Leonov et al. 2009). In such cases, hybrids produced gametes with the genome of one parental species only. In fewer cases, hybrids produce both $\mathrm{L}$ and $\mathrm{R}$ gametes. This phenomenon was previously considered as an abnormal deviation (Bucci et al. 1990; Vinogradov et al. 1991; Berger and Günther 1992). However, the latter hybrids were found in many samples from the Seversky Donets River drainage (Table 1). Importantly, such gametogenesis was observed in both diploid and triploid hybrids of both sexes.

Formerly, it was assumed that LLR hybrids usually produced gametes with the L genome, while LRR hybrids rendered gametes with the R genome (Berger and Günther 1988; Plötner 2005). In general, this regularity was also confirmed for frogs from the Seversky Donets River drainage. However, here some triploids produced a mixture of haploid gametes with genomes of both parental species (Table 1). Before, triploids producing several gamete kinds at once were revealed in Germany, Sweden, Denmark and Hungary (Berger and Günther 1988, 1992; Berger and Berger 1994; Brychta and Tunner 1994; Christiansen et al. 2005; Christiansen 2009). Moreover, in north-eastern Ukraine, a hybrid LLR female from Gaidary produced gametes with the R genome, whereas a LRR female from Sukhaya Gomolsha village had gametes with the L genome only (Table 1). Before, LLR males with $\mathrm{R}$ gametes were recorded in Danish populations (Christiansen et al. 2005), whereas LRR frogs with L gametes were previously not mentioned.

The failure of clonal inheritance in diploid P. esculentus was repeatedly mentioned in various studies (Heppich and Tunner 1979; Tunner 1980; Vinogradov et al. 1990; Tunner and Heppich-Tunner 1991; Ragghianti et al. 2007). We also found few, probably, recombinant diploid hybrids in the Seversky Donets River drainage. Their genome size was intermediate between that of P. esculentus and P. ridibundus (Borkin et al. 2004). Perhaps, such individuals originated from crossings of frogs with gametes of $P$. ridibundus and $P$. esculentus, which produced gametes with intermediate genome. Three hybrid males providing such gametes were recorded in our studies (Table 1).

Provisionally, all studied HPS of north-eastern Ukraine can be divided into three groups with different geographical distribution. Group I inhabits the right tributaries of the Seversky Donets River and consists of diploid hybrids and P. ridibundus (localities 1-6; Fig. 1). The RR-LR system type is common in other regions of forest-steppe zones of Russia, Ukraine and Moldavia as well (Lada et al. 2011; Morozov-Leonov 2014). According to our data, hybrids in this system come from crosses of $P$. ridibun$d u s$ (or hybrids with gametes of $P$. ridibundus) and $P$. esculentus, which produce a mixture of haploid gametes with genomes of both parental species (hybrid amphispermy) and, sometimes, intermediate genome.

Group II includes HPS which consist of triploid LLR females and P. ridibundus (RR-LLR $\mathrm{f}_{\mathrm{f}}$ type; localities 17-18; Fig. 1). These systems are distributed in the eastern part of Donetsk and Luhansk oblasts of Ukraine as well as in the western part of Rostov Oblast of Russia (Borkin et al. 2004, 2005, 2006; our data). Here, hybrids are descended from crosses of hybrid females with P. ridibundus males. Duplication of clonal L genome in mature eggs might result from the suppression of second polar body formation or from extra precleavage endoreduplication.

Group III (localities 7-16) is geographically intermediate between Groups I and II. Triploid hybrids in local population systems varied from $3 \%$ to $100 \%$ (Table 1) and among them LRR frogs were predominant. Here, some diploid females can produce diploid gametes (Dedukh et al. 2015). Fertilization of diploid eggs by haploid L or R sperm results in the origin of triploid LLR and LRR hybrids. Hybrids produce haploid gametes with the L genome giving rise to new diploid hybrids. Theoretically, fertilization of L haploid eggs by spermatozoa carrying the $\mathrm{L}$ genome can lead to the origin of P. lessonae. Indeed, formerly, we identified single young individuals of the species in these populations (Borkin et al. 2004). However, progeny with clonal genomes only is not viable (Berger 1968; Blankenhorn et al. 1971; Vorburger 2001; Guex et al. 2002).

Our investigation of green frogs from Seversky Donets River drainage is ongoing. Many questions are still to be answered. It was unexpected, that the majority of $P$. esculentus would not pass $\mathrm{L}$ genome in gametes, taking in account the complete 
absence of adult $P$. lessonae in this region. Furthermore, the mass occurrence of hybrids with two germ cell lines $(\mathrm{R}+\mathrm{L})$ in gonads has never been reported before. In addition, according to our findings from two populations, we can assert the reproduction of triploid females via a doubling of $\mathrm{L}$ genomes after fertilization. These results suggest that local HPS in the Seversky Donets River drainage are more diverse and complex than previously thought. Mating system, gametes production pattern, and even cytological mechanisms now appear to be different in various populations of the $P$. esculentus complex.

\section{Acknowledgements}

We thank A. O. Svinin (Kazan, Russia) for providing P. lessonae samples, O. I. Sinna (Kharkiv, Ukraine) for the help with drawing of a map and J. Newman (Glasgow Caledonian University, United Kingdom) for checking the English text. The work was partially supported by grants of Russian Foundation of Basic Research 15-04-05068 and NSh.3553.2014.4.

\section{References}

Arioli M, Jakob C, Reyer HU (2010) Genetic diversity in water frog hybrids (Pelophylax esculentus) varies with population structure and geographic location. Mol Ecol 19:1814-1828.

Arnold M (2006) Evolution through Genetic Exchange. Oxford University Press, USA.

Berger L (1968) Morphology of the F1 generation of various crosses within Rana esculenta-complex. Acta Zool Cracoviensia 13:301-324.

Berger L (1994) Some peculiar phenomena in European water frogs. Zool Pol 39:267-280.

Berger L, Berger WA (1992) Progeny of water frog populations in central Poland. Amphibia-Reptilia 13:135-146.

Berger L, Berger WA (1994) Persistence of all-hybrid water frog populations (Rana kl. esculenta) in northern Germany. Genet Pol 35:73-80.

Berger L, Günther R (1988) Genetic Composition and Reproduction of Water Frog Populations (Rana kl. esculenta Synklepton) Near Nature Reserve Serrahn, GDR. Arch. Nat. schutz. Landsch. forsch., Berlin.

Berger L, Günther R (1992) Inheritance patterns of water frog males from the environments of Nature Reserve Steckby, Germany. Zool Pol 37:87-100.

Berger L, Roguski H (2002) Characteristics of diploid and triploid kintadpoles of Polish water frogs. Biol Lett 39:29-42.

Berger L, Roguski H, Uzzell T (1978) Triploid F2 progeny of water frogs (Rana esculenta complex). Folia Biol (Praha) 26:135-152.

Blankenhorn H, Heusser H, Vogel P (1971) Drei Phänotypen von Grünfröschen aus dem Rana esculenta-Komplex in der Schweiz. Rev Suisse Zool 78:1242-1247.

Bogart JP, Bi K (2013) Genetic and genomic interactions of animals with different ploidy levels. Cytogenet Genome Res 140:117-136.

Borkin LJ, Darevsky IS (1980) Reticulate (hybridogenous) speciation in vertebrates. J Gen Biol Moscow 41:485-506.

Borkin LJ, Litvinchuk SN (2013) Animal hybridization, speciation and systematics. Proc Zool Institute, Russ Acad Sci 2:83-139.

Borkin LJ, Vinogradov AE, Rosanov JM, Tsaune IA (1987) Hemiclonal inheritance in the hybridogenetic complex Rana esculenta: evidence by method of flow DNA cytometry. Dokl Akad Nauk SSSR 295:12611264.

Borkin LJ, Litvinchuk SN, Rosanov JM, Milto KD (2001) Cryptic speciation in Pelobates fuscus (Anura, Pelobatidae): evidence from DNA flow cytometry. Amphibia-Reptilia 22:387-396.

Borkin LJ, Korshunov AV, Lada GA, Litvinchuk SN, Rosanov JM, Shabanov DA, Zinenko AI (2004) Mass occurrence of polyploid green frogs (Rana esculenta complex) in eastern Ukraine. Russ J Herpetol 11:194-213.

Borkin LJ, Zinenko AI, Korshunov AV, Lada GA, Ltvinchuk SN, Rosanov JM, Shabanov DA (2005) Mass polyploidy in Rana esculenta hybridogenic complex (Ranidae, Anura, Amphibia) in eastern Ukraine. In: Pisanets E (ed), Proceedings of the 1st Conference of the Ukrainian
Herpetological Society. Zoomuseum NMNH NAS of Ukraine, Kyiv, pp 23-26.

Borkin LJ, Lada GA, Litvinchuk SN, Melnikov DA, Rosanov JM (2006) The first record of mass triploidy in hybridogenic green frog Rana esculenta in Russia (Rostov Oblast'). Russ J Herpetol 13:77-82.

Brychta BH, Tunner HG (1994) Flow cytometric analysis of spermatogenesis in triploid Rana esculenta. Zool Pol 39:507.

Bucci S, Ragghianti M, Mancino G, Berger L, Hotz H, Uzzell T (1990) Lampbrush and mitotic chromosomes of the hemiclonally reproducing hybrid Rana esculenta and its parental species. J Exp Zool 255:37-56.

Christiansen DG (2009) Gamete types, sex determination and stable equilibria of all-hybrid populations of diploid and triploid edible frogs (Pelophylax esculentus). BMC Evol Biol 9:135.

Christiansen DG, Reyer H-U (2009) From clonal to sexual hybrids: genetic recombination via triploids in all-hybrid populations of water frogs. Evolution 63:1754-68.

Christiansen DG, Fog K, Pedersen BV, Boomsma JJ (2005) Reproduction and hybrid load in all-hybrid populations of Rana esculenta water frogs in Denmark. Evolution 59:1348-1361.

Christiansen DG, Jakob C, Arioli M, Roethlisberger S, Reyer H-U (2010) Coexistence of diploid and triploid hybrid water frogs: population differences persist in the apparent absence of differential survival. BMC Ecol 10:1-14. doi:10.1186/1472-6785-10-14

Cunha C, Ignacio D, Coelho MM (2008) Speciation towards tetraploidization after intermediate processes of non-sexual reproduction. Philos Trans R Soc Lond B Biol Sci 363:2921-2929.

Dawley RM (1989) An introduction to unisexual vertebrates. In: Dawley RM, Bogart JP (eds), Evolution and Ecology of Unisexual Vertebrates. New York State Museum Bulletin 466, New York State Museum, Albany, NY, pp 1-18.

Dedukh D, Litvinchuk S, Rosanov J, Mazepa G, Saifitdinova A, Shabanov D, Krasikova A (2015) Optional endoreplication and selective elimination of parental genomes during oogenesis in diploid and triploid hybrid european water frogs. PLoS ONE 10:1-19.

Frost DR, Grant T, Faivovich J, Bain RH, Haas A, Haddad CFB, De Sá RO, Channing A, Wilkinson M, Donnellan SC, Raxworthy CJ, Campbell J, Blotto BL, Moler P, Drewes RC, Nussbaum R, Lynch JD, Green DM, Wheeler WC (2006) The amphibian tree of life. Bull Am Mus Nat Hist 297:1-291.

Graf JD, Müller WP (1979) Experimental gynogenesis provides evidence of hybridogenetic reproduction in the Rana esculenta complex. Experientia 35:1574-1576.

Graf JD, PollsPelaz M (1989a) Evolutionary genetics of the Rana esculenta complex. In: Dawley RM, Bogart JP (eds), Evolution and Ecology of Unisexual Vertebrates. New York State Museum Bulletin 466, New York State Museum, Albany, NY, pp 289-302

Graf JD, PollsPelaz M (1989b) Cytogenetic analysis of spermatogenesis in unisexual allotriploid males from a Rana lessonae-Rana kl. esculenta mixed population. In: Hallida T, Baker J, Hosie L (eds), Abstrs. of the First Congr. of Herpetol. University of Kent, Canterbury, United Kingdom, p 126.

Guex G-D, Hotz H, Semlitsch RD (2002) Deleterious alleles and differential viability in progeny of natural hemiclonal frogs. Evolution 56:1036-1044.

Günther R (1975a) Untersuchungen der Meiose bei Mänchen von Rana ridibunda Pall., Rana lessonae Cam. und der Bastardform, "Rana esculenta" L. (Anura). Biol Zent B1 94:277-294.

Günther R (1975b) Zum naturlichen vorkommen und zur Morphologie triploider Teichfrosche, Rana "esculenta", L., in der DDR (Anura, Ranidae). Mitt Zool Mus Berlin 51:145-158

Günther R (1983) Zur Populationsgenetik der mitteleuropaischen Wasserfrosche des Rana eseulenta- Synkleptons (Anura, Ranidae). Zool Anz 211:43-54.

Gunther R, Plötner J (1988) Zur Problematik der klonalen Vererbung bei Rana kl. esculenta (Anura). In: Günther R, Klewen R (eds), Beiträge zur Biologie und Bibliographie (1960-1987) der europäischen Wasserfrösche, volume 1, Jahrbuch für Feldherpetologie, Beiheft Duisburg, pp 23-46.

Günther R, Uzzell T, Berger L (1979) Inheritance patterns in triploid "Rana esculenta" (Amphibia, Salientia). Mitt Zool Mus Berlin 55:35-57.

Heppich S, Tunner HG (1979) Chromosomal constitution and c-banding in homotypic Rana esculenta crosses. Mitt Zool Mus Berlin 55:111-114. 
Heppich S, Tunner HG, Greilhuber J (1982) Premeiotic chromosome doubling after genome elimination during spermatogenesis of the species hybrid Rana esculenta. Theor Appl Genet 61:101-104.

Hoffmann A, Plötner J, Pruvost NB, Christiansen DG, Röthlisberger S, Choleva L, Mikulíček P, Cogălniceanu D, Sas-Kovács I, Shabanov D, Morozov-Leonov S, Reyer HU (2015) Genetic diversity and distribution patterns of diploid and polyploid hybrid water frog populations (Pelophylax esculentus complex) across Europe. Mol Ecol 24:4371-4391.

Jakob C (2007) Structure and Dynamics of Pure Hybridogenetic Water Frog Populations of Rana esculenta in Southern Sweden. PhD Dissertation. Universität Zürich.

Kawahara H (1978) Production of triploid and gynogenetic diploid xenopus by cold treatment. Dev Growth Differ 20:227-236.

Kondo Y (2002) Developmental capacity and chromosome number in the offspring of artificially produced autotetraploids of Rana nigromaculata. Zoolog Sci 19:877-883.

Korshunov OV (2010) Ecological Patterns in Biotopic Distribution of Pelophylax Esculentus Complex Within the Upper Seversky Donets Drainage. Oles' Gonchar Dnipropetrovsk National University, Dnipropetrovsk.

Lada GA, Borkin LJ, Vinogradov AE (1995) Distribution, population systems and reproductive behavior of green frogs (Hybridogenetic Rana esculenta Complex) in the Central Chernozem Territory of Russia. Russ J Herpetol 2:46-57.

Lada GA, Borkin LJ, Litvinchuk SN, Rosanov JM (2011) Types of population systems of green frogs (Rana esculenta complex) in the territory of the Russian Plain' Territory. In: Ananjeva NB (ed), Problems of Herpetology, St. Petersburg, pp 142-148.

Litvinchuk SN, Rosanov JM, Borkin LJ (1998) A case of natural triploidy in a smooth newt Triturus vulgaris (Linnaeus, 1758), from Russia (Caudata: Salamandridae). Herpetozoa 11:93-95.

Mallet J (2007) Hybrid speciation. Nature 446:279-283.

Mallet J (2008) Hybridization, ecological races and the nature of species: empirical evidence for the ease of speciation. Philos Trans R Soc Lond B Biol Sci 363:2971-2986.

Manilo VV, Radchenko VI (2010) Karyological study of Pelophylax ridibundus (Anura, Amphibia) in the eastern part of Ukraine. $\mathrm{Zb} \mathrm{Pr}$ Zool Museyu, Kyiv 41:111-121.

Manilo VV, Radchenko VI, Korshunov AV (2007) Comparative karyological analysis of edible frog (Rana kl esculenta Linnaeus, 1758) from the Kharkov region of Ukraine. Nauk Visn Uzhgorod Univ Biol 21:68-73.

Mezhzherin SV, Morozov-Leonov SY, Nekrasova OD, Kurtyak FF, Shabanov DA, Korshunov AV (2007) Evolutionary genetic aspects of the hybrid form Rana kl. esculenta (Amphibia, Ranidae) hemiclonal reproduction. Nauk Visn Uzhgorod Univ Biol 21:79-84.

Mezhzherin SV, Morozov-Leonov SI, Rostovskaia OV, Shabanov DA, Sobolenko LI (2010) Ploidy and genetic structure of hybrid populations of water frogs Pelophylax esculentus (L., 1758) complex (Amphibia, Ranidae) of Ukraine. Tsitol Genet 44:23-28.

Mikulicek P, Kotik P (2001) Two water frog populations from western Slovakia consisting of diploid females and diploid and triploid males of the hybridogenetic hybrid Rana esculenta (Anura, Ranidae). Mitt Mus Nat.kd Berl, Zool R 77:59-64.

Mikulíček P, Kautman M, Kautman J, Pruvost NBM (2015) Mode of hybridogenesis and habitat preferences influence population composition of water frogs (Pelophylax esculentus complex, Anura: Ranidae) in a region of sympatric occurrence (western Slovakia). J Zool Syst Evol Res 53:124-132.

Morozov-Leonov SY (2014) Hybridization of Amphibians: The Populations at Structure, Evolutionary Sense, the Status of Hybrid Biotypes. I. I. Schmalhausen zoology institute of Zoology National Academy of sciences of Ukraine, Kyiv.

Morozov-Leonov SY, Mezhzherin SV, Nekrasova OD, Kurtyak FF (2007) Hybrid population of european water-frogs: a review of data on the quantitative genetic composition. Usp Sovrem Biol 127:98-106.

Morozov-Leonov SY, Mezhzherin SV, Nekrasova OD, Shabanov DA, Korshunov AV, Krutyak FF (2009) Inheritance of parental genomes by a hybrid form Rana "esculenta" (Amphibia, Ranidae). Russ J Genet 45:423-429.
Ogielska M (1994) Nucleus-like bodies in gonial cells of Rana esculenta (Amphibia, Anura) tadpoles - a putative way of chromosome elimination. Zool Pol 39:461-474.

Olsen MW (1974) Frequency and cytological aspects of diploid parthenogenesis in turkey eggs. Theor Appl Genet 44:216-221.

Otto SP, Whitton J (2000) Polyploid incidence and evolution. Annu Rev Genet 34:401-437.

Plötner J (2005) Die westpalaarktischen Wasserfrosche. Laurenti-Verlag, Bielefeld.

Pruvost NBM, Hoffmann A, Reyer H-U (2013) Gamete production patterns, ploidy, and population genetics reveal evolutionary significant units in hybrid water frogs (Pelophylax esculentus). Ecol Evol 3:29332946.

Ragghianti M, Bucci S, Marracci S, Casola C, Mancino G, Hotz H, Guex G-D, Plötner J, Uzzell T (2007) Gametogenesis of intergroup hybrids of hemiclonal frogs. Genet Res 89:39-45.

Rostovska OV (2011) Geographical Patterns of Structural Changes of Green Frog Hybrid Populations of the Pelophylax esculentus complex (Linnaeus, 1758) in Ukraine. PhD Dissertation. I. I. Schmalhausen Institute of Zoology, National Academy of Sciences, Kyiv.

Rybacki M (1994a) Pure populations of a hybrid Rana esculenta from the German-Polish Usedom Island. Zool Pol 39:519-520.

Rybacki M (1994b) Diploid males of Rana esculenta from natural populations in Poland producing diploid spermatozoa. Zool Pol 39:517-518.

Rybacki M, Berger L (2001) Types of water frog populations (Rana esculenta complex) in Poland. Mitt Mus Nat.kd Berl, Zool R 77:51-57.

Schröer T (1996) Morphologie und Ploidiegrade von Wasserfröschen aus unterschiedlichen Populationssystemen in Nordost-Polen. Zeitschrift für Feldherpetologie 4:37-54.

Schultz RJ (1969) Hybridization, unisexuality, and polyploidy in the teleost Poeciliopsis (Poeciliidae) and other vertebrates. Am Nat 103:605-619. Am Nat 29: 605-619.

Shabanov DA (2015) Evolutionary Ecology of Population Systems of Green Frogs' Hybridogenetic Complex (Pelophylax esculentus complex) from Left Bank Forest-Steppes of Ukraine. Doctoral Dissertation. Oles' Gonchar Dnipropetrovsk National University, Dnipropetrovsk.

Shabanov DA, Litvinchuk SN (2010) Green frogs: life without rules or special way of evolution? Prir Moscow 3:29-36.

Suryadna NN (2010) New records of triploids of Pelophylax esculentus (Linnaeus, 1758) in eastern Ukraine. Curr Stud Herpetol Saratov 10:128-131.

Tunner HG (1974) Die klonale struktur einer wasserfroschpopulation. Z zool Syst Evol -forsch 12:309-314.

Tunner HG (1980) Kreuzungsexperimente mit wasserfröschen aus österreichischen und polnischen mischpopulationen (Rana lessonae + Rana esculenta) Eine analyse bichemischer und morphologischer merkmale. Z F Zool Syst u Evol 18:257-297.

Tunner HG, Heppich S (1981) Premeiotic genome exclusion during oogenesis in the common edible frog, Rana esculenta. Naturwissenschaften 68:207-208.

Tunner HG, Heppich-Tunner S (1991) Genome exclusion and two strategies of chromosome duplication in oogenesis of a hybrid frog. Naturwissenschaften 78:32-34.

Tunner HG, Heppich-Tunner S (1992) A new population system of water frogs discovered in Hungary. In: Korsós ZK (ed), Proc. of the Sixth Ordinary General Meeting of the Societas Europaea Herpetologica, 19-23 August, Hungarian Natural History Museum, Budapest, pp 453-460.

Uzzell T, Berger L (1975) Electrophoretic phenotypes of Rana ridibunda, Rana lessonae, and their hybridogenetic associate, Rana esculenta. Proc Acad Nat Sci Philadelphia 127:13-24.

Uzzell T, Günther R, Berger L (1977) Rana ridibunda and Rana esculenta: a leaky hybridogenetic system (Amphibia Salientia). Proc Acad Nat Sci Philadelphia 128:147-171.

Uzzell T, Hotz H, Berger L (1980) Genome exclusion in gametogenesis by an interspecific Rana hybrid: evidence from electrophoresis of individual oocytes. J Exp Zool 214:251-259.

Vinogradov AE, Rosanov JM, Tsaune IA, Borkin LJ (1988) Elimination of genome of one of parental species before premeiotic synthesis of 
DNA in hybridogenetic species Rana esculentus. Tsitologiya, Leningr 30:691-698.

Vinogradov AE, Borkin LJ, Günther R, Rosanov JM (1990) Genome elimination in diploid and triploid Rana esculenta males: cytological evidence from DNA flow cytometry. Genome 33:619-627.

Vinogradov AE, Borkin LJ, Günther R, Rosanov J (1991) Two germ cell lineages with genomes of different species in one and the same animal. Hereditas 114:245-251.
Vorburger C (2001) Fixation of deleterious mutations in clonal lineages: evidence from hybridogenetic frogs. Evolution 55:2319-2332.

Zhang J, Sun M, Zhou L, Li Z, Liu Z, Li X-Y, Liu X-L, Liu W, Gui J-F (2015) Meiosis completion and various sperm responses lead to unisexual and sexu4l reproduction modes in one clone of polyploid Carassius gibelio. Sci Reports 5:1-14. DOI: 10.1038/srep10898 